\title{
Pengembangan Perangkat Evaluasi Pembelajaran Pendidikan Agama Islam dalam Konteks Kurikulum 2013 Revisi
}

\author{
Dina Mardiana ${ }^{1}$, Suti'ah $^{2}$ \\ ${ }^{1}$ Fakultas Agama Islam, Universitas Muhammadiyah Malang \\ ${ }^{2}$ Fakultas Ilmu Tarbiyah dan Keguruan, Universitas Islam Negeri Maulana Malik Ibrahim Malang
}

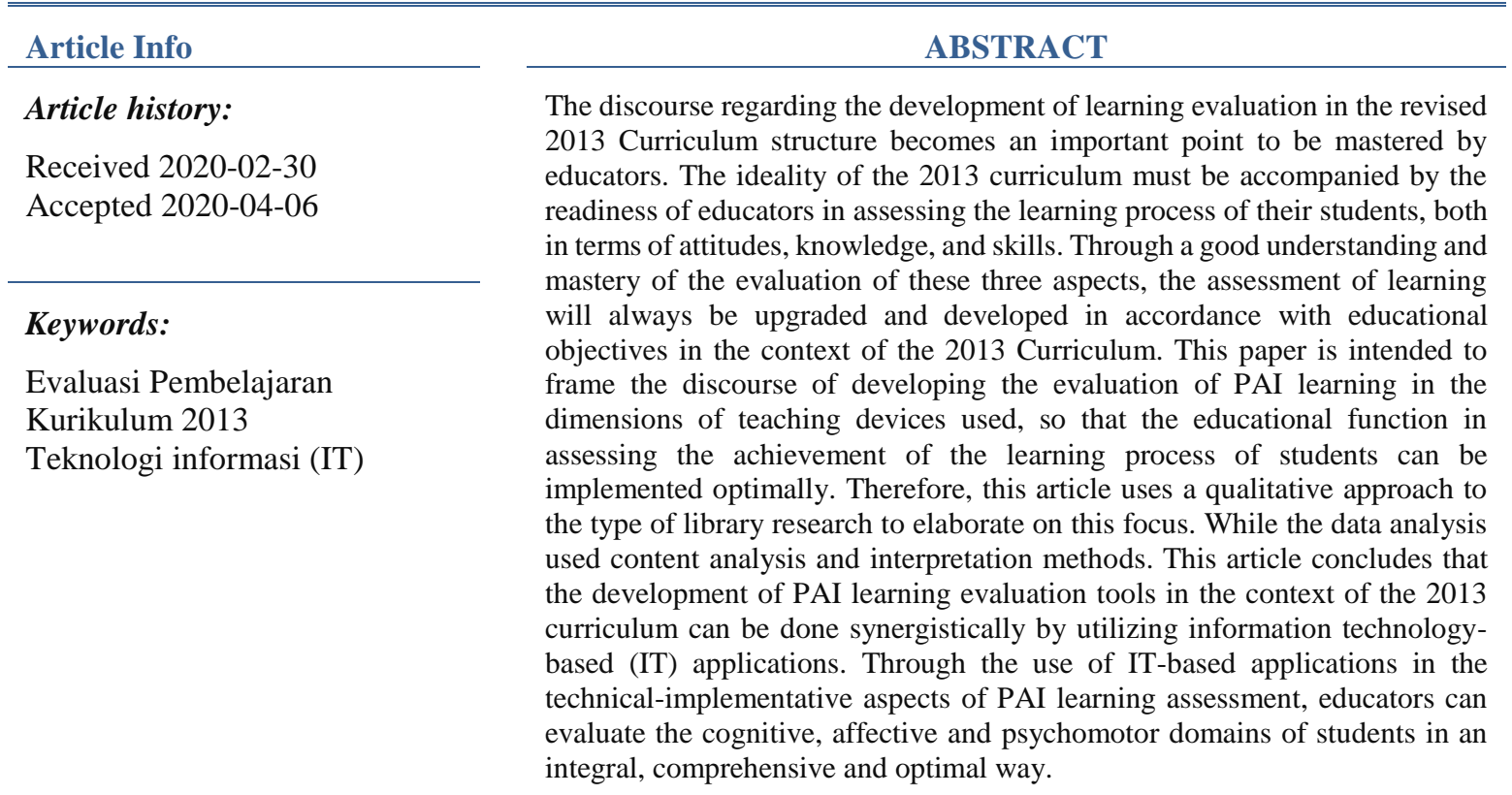

This is an open access article under the CC BY-SA license.

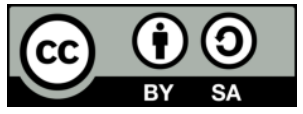

\section{Corresponding Author:}

Dina Mardiana

Program Studi Pendidikan Agama Islam, Universitas Muhammadiyah Malang

Email: dinamardiana@umm.ac.id

\section{PENDAHULUAN}

Evaluasi pembelajaran dalam struktur Kurikulum 2013 memiliki peran dalam memantau progress belajar peserta didik dalam aspek sikap, pengetahuan dan keterampilan (Baswedan, 2015), baik evaluasi yang dilakukan secara manual-konvensional maupun penilaian berbasis online (Setemen, 2010). Pada tiap komponen yang disusun, evaluasi tersebut mencerminkan penilaian komprehensif dalam bidang studi (Syahid, 2018) yang mencirikan output kualitas pendidikan yang telah dilaksanakan selama proses pembelajaran (Sutarman, 2017). Maka, lazim apabila dikatakan bahwa aspek evaluasi pembelajaran merupakan indikator puncak penentu tercapai tidaknya target pembelajaran (Rahmawati, 2017). Melalui evaluasi pembelajaran pula, dapat dilihat etos kerja pendidik dalam mengantar proses belajar peserta didiknya (Sutarman, 2013).

Dalam konteks Kurikulum 2013 revisi -dengan meminjam istilah Azyumardi Azra- terjadi sebuah restrukturisasi kurikulum sebagai upaya pengembangan pendidikan ke arah yang lebih modern (Ach.Sayyi, 2017). Strukturisasi yang dimaksud berlandaskan pada tiga aspek: filosofis, yuridis, serta psikopedagogik. Aspek filosofis mengacu pada basis nilai-nilai luhur yakni nilai akademik, kebutuhan peserta didik dan masyarakat. Disamping itu pula, landasan filosofis kurikulum diorientasikan pada sisi pengembangan kompetensi; Aspek yuridis-formal diantaranya ialah UU No. 20 Tahun 2003 (tentang Sistem Pendidikan 
Nasional pasal 36 (Acuan dan Prinsip Penyusunan Kurikulum), pasal 38 (KTSP), penjelasan Bagian Umum (KBK), serta Penjelasan Pasal 35 (Lingkup Kompetensi)), PP No. 32 Tahun 2013, serta Peraturan Mendikbud No 54, 65, 66, 67, 68, 69 dan 70 Tahun 2013; dan terakhir yaitu aspek psikopedagogik mengacu pada relevansi, model kurikulum berbasis kompetensi, proses pembelajaran (Kegiatan Belajar Mengajar (KBM), output belajar, outcomes belajar), serta penilaian dalam bentuk Authentic Asessment dan kesesuaian teknik penilaian berdasar kompetensi sikap, pengetahuan dan keterampilan (Kemendikbud, 2013).

Salah satu poin restrukturisasi kurikulum tersebut -utamanya terkait penilaian pembelajaran yang dilakukan- ialah adanya penilaian pada domain pengetahuan, keterampilan dan sikap peserta didik. Ketiga domain tersebut memiliki instrumen evaluasi yang berbeda namun saling terkait antara satu dengan lainnya. Apabila dicermati, salah satu aspek penilaian, yakni pada domain sikap, berhilir pada terbentuknya konstruk pendidikan karakter (Hamidi, 2013) yang jelang satu dekade terakhir ini diusung pemerintah melalui kebijakan pendidikan pada tiap level sekolah mulai tingkat PAUD, Sekolah Dasar dan Menengah, hingga level Pendidikan Tinggi.

Konsep adiluhung pengembangan karakter yang termaktub melalui penerapan Kurikulum 2013 Revisi, berkelindan dengan dua aspek penting lainnya yaitu pengembangan sisi pengetahuan (kognitif) dan aspek keterampilan (psikomotorik). Integrasi holistik pengembangan tiga aspek inilah yang menjad penciri dari Kurikulum 2013, terutama pada perkembangannya menjadi Kurikulum 2013 Revisi. Keseluruhan proses yang tercipta di dalam alur Kurikulum 2013 Revisi mulai dari perencanaan pembelajaran, proses pembelajaran, hingga tahap evaluasinya memiliki peran serta urgensitas masing-masing yang akan memperkokoh laju progresivitas menuju tercapainya tujuan pendidikan yang diinginkan.

Oleh karenanya, tulisan ini hendak membingkai diskursus mengenai pengembangan evaluasi pembelajaran di dalam Kurikulum 2013 revisi sebagai poin yang penting untuk dikuasai oleh pendidik. Hal tersebut dikarenakan evaluasi merupakan tahapan akhir penilaian hasil dari proses pembelajaran yang telah dilaksanakan oleh peserta didik dalam sebuah lingkup pendidikan. Melalui pemahaman serta penguasaan yang baik, maka penilaian pembelajaran akan dapat senantiasa diupgrade dan dikembangkan sesuai dengan idealitas tujuan Kurikulum 2013. Perkembangan dinamika arus teknologi dan informasi juga menjadi poin substantif perlunya pengembangan pada bidang penilaian Kurikulum 2013 Revisi tersebut.

\section{METODE}

Untuk penelitian dan pembahasan dalam riset ini, penulis menggunakan jenis penelitian pustaka (Library Research), yaitu penelitian yang obyek utamanya adalah buku-buku perpustakaan dan literaturliteratur lainnya (Hadi, 1995) dengan mengidentifikasikan dan menemukan informasi yang relevan, menganalisis dari informasi tersebut untuk penulis kembangkan dalam bentuk kreasi ide terkait topik yang dianalisa (Elmer E. Rasmuson Library, 2018). Penelitian ini menggunakan metode dokumentasi, dari data sumber primer dan sekunder, setelah itu data yang sudah ada akan penulis kaji kemudian dipaparkan sesuai dengan bahasan penelitian (Surahmad, t.t). Dalam penelitian ini ada dua sumber data yang diperlukan yaitu sumber data primer dan data sekunder. Sumber data primer yaitu sumber asli, merupakan suatu data pokok yang sesuai dengan pembahasan yang akan dikaji. Sedangkan sumber data sekunder yaitu data yang diperoleh dari data-data yang dikumpulkan selain sumber primer (Surahmad, t.t).

Setelah data terkumpul, kemudian diseleksi dan dirangkai ke dalam hubungan fakta-fakta dengan melihat adanya suatu keterkaitan dan keteraturan data, sehingga membentuk suatu pola yang dituangkan dalam bentuk analisis.Adapun dalam menganalisis tersebut penulis menggunakan pola berpikir: Metode Deduktif yaitu mengumpulkan dan mengklarifikasikan data dari berbagai literatur yang mengbahas mengenai tema yang terkait (Hadi, 1995). Deskriptif-Analisis (Baker dan Zubair, 1990), metode ini digunakan peneliti untuk memberikan gambaran data yang berkaitan dengan pengembangan perangkat evaluasi pendidikan kemudian dianalisis dan diinterpretasi.

Dalam penulisan kesimpulan, penulisan riset ini menggunakan metode deduktif, yaitu menarik sebuah kesimpulan atas dasar data-data yang bersifat teoritis untuk suatu kesimpulan fakta yang bersifat khusus (Surahmad, 1989). Dengan menggunakan metode ini diharapkan kesimpulan akhir merupakan hasil penelitian yang bersifat objektif dan dapat dipertanggungjawabkan.

\section{HASIL DAN PEMBAHASAN}

\section{Evaluasi Pembelajaran Pendidikan Agama Islam: Antara Laten dan Manifes}

Secara general, dalam sistem Kurikulum 2013 Revisi, evaluasi pembelajaran pada tingkat satuan pendidikan dilakukan secara satu arah. Subyek yang dinilai adalah peserta didik dengan obyek penilaian bertumpu pada tiga hal: sikap (afektif), pengetahuan (kognitif), serta keterampilan (psikomotorik). Sisi pengetahuan diintegrasikan dengan keterampilan dan sikap guna menunjang ketercapaian pendidikan secara holistik dan komprehensif. Melalui Kurikulum 2013 Revisi, peserta didik diharapkan mampu membangun pengetahuan, keterampilan, maupun sikap bagi tujuan perubahan dan perbaikan martabat 
kehidupan manusia.

Melalui penilaian yang bersifat satu arah tersebut, diharapkan penilaian dari pendidik melalui instrumen dan perangkat evaluasi yang digunakan, mampu menakar hasil proses belajar yang dilaksanakan dalam kurun waktu tertentu. Konsep pendidikan (terutama PAI) menjadi pintu bagi tersemainya potensi peserta didik secara maksimal sehingga menjadi insan produktif yang tetap berpegang pada pengembangan karakter insan kamil: mendidik manusia berkualitas yang akan mampu menjawab dinamisasi tantangan zaman.

Idealitas penilaian yang membidik aspek afektif, kognitif dan psikomotorik para peserta didik, sejatinya menemui banyak kendala yang menghempaskan idealitas tersebut saat bersinggungan dengan realita sesungguhnya. Sebagaimana riset yang dilakukan oleh beberapa peneliti, mengungkap ketimpangan idealitas konsep evaluasi dengan ranah praksis yang dihadapi oleh para pendidik di satuan pendidikan masing-masing. Diantaranya ialah riset Friantary (Friantary \& Martina, 2018) yang menyimpulkan bahwa terjadi gap kesenjangan antara standar absolut pelaksanaan dengan implementasi penilaian hasil belajar siswa yang dilakukan oleh guru, atau riset Nuruzzaman yang meneropong kompleksitas format penilaian Kurikulum 2013 sebagai salah satu faktor penghambat dalam pengimplementasian kurikulum tersebut di sekolah (Fuady, A., \& Nursit, 2016), juga riset Riana, dkk. (Riana, Agung, \& Parmiti, 2016) dan riset Nuruzzaman (Nuruzzaman, 2015) yang menyoroti ketimpangan idealitas perencanaan pembelajaran melalui RPP Kurikulum 2013 dengan keterlaksanaannya oleh para pendidik di satuan pendidikan.

Melalui beberapa riset tersebut, secara teknis nampak bahwa perangkat evaluasi dalam Kurikulum 2013 Revisi secara ideal telah menjangkau ketiga scope penilaian peserta didik -sebagaimana uraian sebelumnya- yang membutuhkan kecermatan, ketelitian, dan kesabaran pendidik sehingga semua unsur penilaian dapat diselesaikan secara tuntas. Namun, idealitas tersebut menemui paradoksitasnya tatkala bersinggungan dengan aspek teknis-implementatifnya di lapangan, yang dirasakan sendiri oleh para pendidik selaku motor pembelajaran di kelas. Pada penilaian aspek sikap misalnya, terdapat instrumen jurnal harian yang mewadahi penilaian pada perilaku peserta didik dalam keseharian aktivitasnya di sekolah. Pendidik -dalam kapasitasnya sebagai evaluator- berkewajiban mencatat setiap perilaku (baik positif maupun negatif) dari peserta didiknya secara individual. Maka, dapat dibayangkan kepadatan aktivitas seorang pendidik dalam menilai aspek sikap. Terlebih lagi, kondisi tersebut akan sangat dirasakan apabila kapasitas pendidik masih belum proporsional dengan jumlah peserta didik.

Begitu pula halnya dengan aspek penilaian pengetahuan dan keterampilan peserta didik. Dalam struktur kurikulum 2013 telah diformulasikan instrumen-instrumen yang wajib dipahami dan dilaksanakan oleh pendidik guna menunjang tiap aspek perkembangan belajar peserta didiknya, terutama pada sisi kognitif dan psikomotorik. Pertanyaannya ialah, apakah idealitas kurikulum tersebut telah bersinergi dengan kesiapan para pendidik di satuan pendidikan masing-masing? jika memang telah bersinergi, lantas apakah sinergitas tersebut mampu berpacu dengan dinamisnya perkembangan teknologi informasi yang semakin masiv dewasa ini?

Melihat fokus permasalahan tersebut, lazim apabila kemudian jika jawaban dari pertanyaanpertanyaan tersebut dapat diajukan menjadi landasan ontologis yang diharapkan mampu mendorong peningkatan mutu pendidikan -termasuk Pendidikan Agama Islam didalamnya- sehingga kesenjangan antara yang laten dan manifes dunia kependidikan Islam dapat tereduksi secara perlahan, termasuk istilah "bias dalam penilaian" (Abidin, 2016).

Istilah tersebut sejatinya merujuk pada ihwal ketidakmampuan sebuah instrumen penilaian dalam mengukur kemampuan peserta didik yang semestinya. Dengan kata lain, secara ideal kualitas penilaian peserta didik hendaklah dapat diukur secara jelas dan konkrit sesuai dengan kondisi yang sebenarnya, meskipun menggunakan instrumen penilaian yang bervariasi -sebagaimana penerapan di dalam Kurikulum 2013- selama ini. Melalui penilaian multiaspek, diharapkan seluruh potensi peserta didik dapat terekam sekaligus dapat melewati proses belajar, sehingga menghantarkan peserta didik menjadi manusia berpengetahuan yang paham akan makna belajar. Sebagaimana kesimpulan penelitian yang dilakukan oleh Fauziya menyebutkan bahwa indikator tingkat keberhasilan penilaian autentik dapat dilihat dari terjalinnya integrasi nyata dari kompetensi sikap, pengetahuan, maupun keterampilan pada diri peserta didik. Integrasi ketiga aspek tersebut mewujud pada lahirnya kompetensi karakter peserta didik yang kreatif, produktif, mamiliki keterampilan sekaligus juga berpengetahuan (Gahara, 2016).

Melalui paparan tersebut, dapat disimpulkan bahwa salah satu unsur penunjang dalam upaya ketercapaian proses belajar dalam Kurikulum 2013 ialah pada aspek pengembangan perangkat evaluasi pembelajaran yang efektif dan efisien. Hal tersebut mutlak diperlukan oleh pendidik dalam melaksanakan tugsnya sebagai evaluator pembelajaran (Ghofar, 2017), sehingga penilaian terhadap aspek afektif, kognitif dan psikomotorik dapat terekam dengan baik dan tuntas. Meski dalam beberapa hal hasil belajar peserta didik juga dapat ditingkatkan melalui optimalisasi model pembelajaran berbasis digital (Ramli, 2017), akan tetapi hal tersebut pun juga akan berhilir pada proses penilaian hasil belajar peserta didik sebagai media 
takaran keberhasilan tingkat pendidikan yang telah berlangsung selama proses Kegiatan Belajar Mengajar (KBM).

Pada akhirnya, penilaian pembelajaran menjadi satu poin urgen yang selayaknya mendapat porsi perhatian khusus dari pendidik dalam menuntaskan proses pembelajaran yang telah dilakukan oleh para peserta didiknya. Evaluasi pembelajaran tersebut pada hakikatnya merupakan neraca akhir dalam menilai ketuntasan belajar peserta didik yang -secara ideal- harus linear dan sepadan antara konsep (baca: laten) dan realita (baca: manifes).

\section{Arah Pengembangan Perangkat Evaluasi PAI dalam Konteks Kurikulum 2013 Revisi}

Secara umum, standar penilaian kurikulum 2013 Revisi memiliki penekanan pada sisi pedagogik nonkonvensional dalam proses pembelajaran yang dilaksanakan. Tahapan dalam penerapan penilaian pembelajaran dimulai dengan perencanaan penilaian, pelaksanaan penilaian, analisis dan pengolahan, serta tahap terakhir berupa penyajian hasil penilaian. Setiap tahapan penlaian sebagaimana deskripsi tersebut, dilakukan berdasar pada authentic assessment atau penilaian autentik yang bertujuan untuk memperbaiki program pembelajaran, sehingga pada muaranya diharapkan mempu meningkatkan mutu pendidikan (Umami, 2018). Oleh karenanya, penilaian dilaksanakan dengan menggunakan alat atau instrumen penilaian yang bervariasi, sesuai dengan ketentuan yang terdapat dalam kurikulum 2013, yakni:

Pertama, pada aspek pengetahuan menggunakan instrumen soal uraian untuk tes tulis; instrumen daftar pertanyaan untuk tes lisan; serta instrumen PR (Pekerjaan Rumah) untuk teknik penugasan. Kedua, penilaian pada aspek keterampilan menggunakan tes praktik dalam bentuk demostrasi (unjuk kerja) serta penilaian proyek dengan bentuk instrumen checklist. Ketiga, instrumen penilaian aspek sikap menggunakan bentuk jurnal harian yang berisi catatan guru, serta penilaian dari guru Bimbingan Konseling (BK) dan PKn.

Melalui ketiga ketentuan yang terdapat dalam sistem kurikulum 2013 tersebut, maka secara garis besar penilaian pembelajaran dapat dipilah menjadi dua bentuk, yaitu penilaian formatif dan penilaian sumatif. Bentuk pertama merujuk pada penilaian yang berlangsung selama proses pembelajaran berlangsung, baik pembelajaran di dalam kelas maupun outdoor. Penilaian formatif ini digunakan oleh pendidik untuk membantu mengidentifikasi kekuatan sekaligus kelemahan (strengthness and weakness) yang dimiliki para peserta didik sehingga dapat digunakan sebagai alat koreksi untuk meningkatkan kualitas belajar mereka. Sedangkan bentuk kedua yakni penilaian sumatif biasanya dilakukan pada setiap akhir unit yang diajarkan. Lain halnya dengan penilaian formatif, penilaian sumatif dirancang untuk memberikan informasi kepada pendidik tentang status prestasi peserta didik pada tiap akhir semester. Maka, penilaian portofolio menjadi salah satu contoh penilaian sumatif yang ada dalam sistem kurikulum 2013.

Sebagaimana deskripsi pada uraian sebelumnya, dapat dikatakan bahwa arah pengembangan perangkat evaluasi PAI di masa yang akan datang membutuhkan kerjasama yang besifat dialogis dan sinergis dengan aspek teknologi informasi (IT). Hal tersebut perlu dilakukan guna menunjang ketercapaian target evaluasi pembelajaran yang diinginkan secara holistik sekaligus komprehensif. Konsep penilaian yang holistik -baik pada aspek afektif, kognitif dan psikomotorik- dapat terimplementasikan dengan lebih mudah jika ditunjang oleh perangkat pembelajaran berbasis IT (Setiawan, W., Abdulkarim, A., \& Nugraha, 2018). Terlebih jika dikaitkan dengan modernitas zaman yang menuntut progresivitas berbagai lini termasuk lini pendidikan, maka karakteristik pembelajaran berbasis IT (Mardiana \& Anggraini, 2019) mutlak mendapat respon yang positif. Dengan demikian, proyeksi modernisasi pendidikan Islam dapat diprediksikan dengan baik (Dewantoro, 2014).

Satu hal yang secara teknis dapat dilakukan, ialah dengan menerapkan penilaian pembelajaran PAI dengan menggunakan instrumen berbasis aplikasi. Implikasi dari adanya sinergitas-dialogis pembuatan perangkat pembelajaran dengan pemanfaatan IT tersebut, salah satunya ialah efektivitas waktu dan tenaga para pendidik dalam mempersiapkan perangkat ajar yang dibutuhkannya. Salah satu contoh ketika struktur kurikulum 2013 mewajibkan pendidik untuk melakukan penilaian aspek pengetahuan maupun keterampilan para peserta didiknya, maka input Kompetensi Inti (KI) dan Kompetensi Dasar (KD) dalam mengisi form penilaian sikap tersebut tidak lagi harus dilakukan secara manual, akan tetapi dapat digantikan dengan penggunaan aplikasi berbasis IT yang secara otomatis akan menampilkan KI dan KD yang ingin dinilai dari peserta didik. Tentu saja, KI dan KD tersebut telah beracuan pada Permendikbud yang berlaku dalam sistem Kurikulum 2013 Revisi, sebagaimana nampak pada gambar berikut ini: 
GAMBAR 1. BERBASIS APLIKASI TABEL YANG

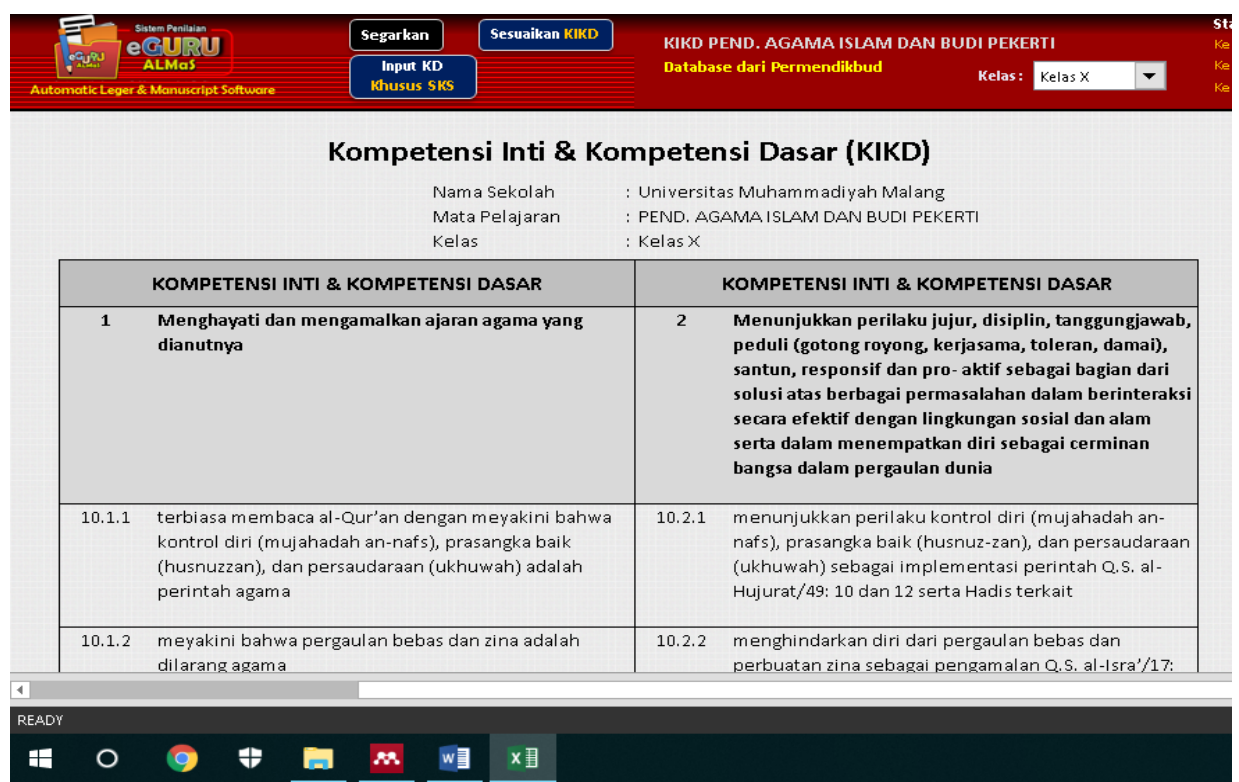

Hal yang sama dapat dilakukan oleh pendidik, dalam menilai aspek sikap. Melalui aplikasi berbasis IT, format penilaian dapat disusun oleh pendidik dengan mengunduh di aplikasi yang tersedia. Detail item yang terdapat dalam format penilaian sikap, mengharuskan pendidik mengeksplor dan mencatat perkembangan setiap peserta didik pada aspek afektif, baik pada saat pembelajaran di kelas maupun di luar kelas. Melalui pemanfaatan IT berbasis aplikasi, proses identifikasi dan dokumentasi tersebut dapat dilakukan oleh pendidik dengan lebih mudah dan tidak membutuhkan waktu relatif lama. Dengan demikian, pendidik dapat melakukan efisiensi waktu dan tenaga dalam memasukkan nilai sikap pada masing-masing peserta didiknya, sebagaimana ilustrasi gambar berikut:

GAMBAR 2. LEMBAR PENILAIAN SIKAP BERBASIS APLIKASI

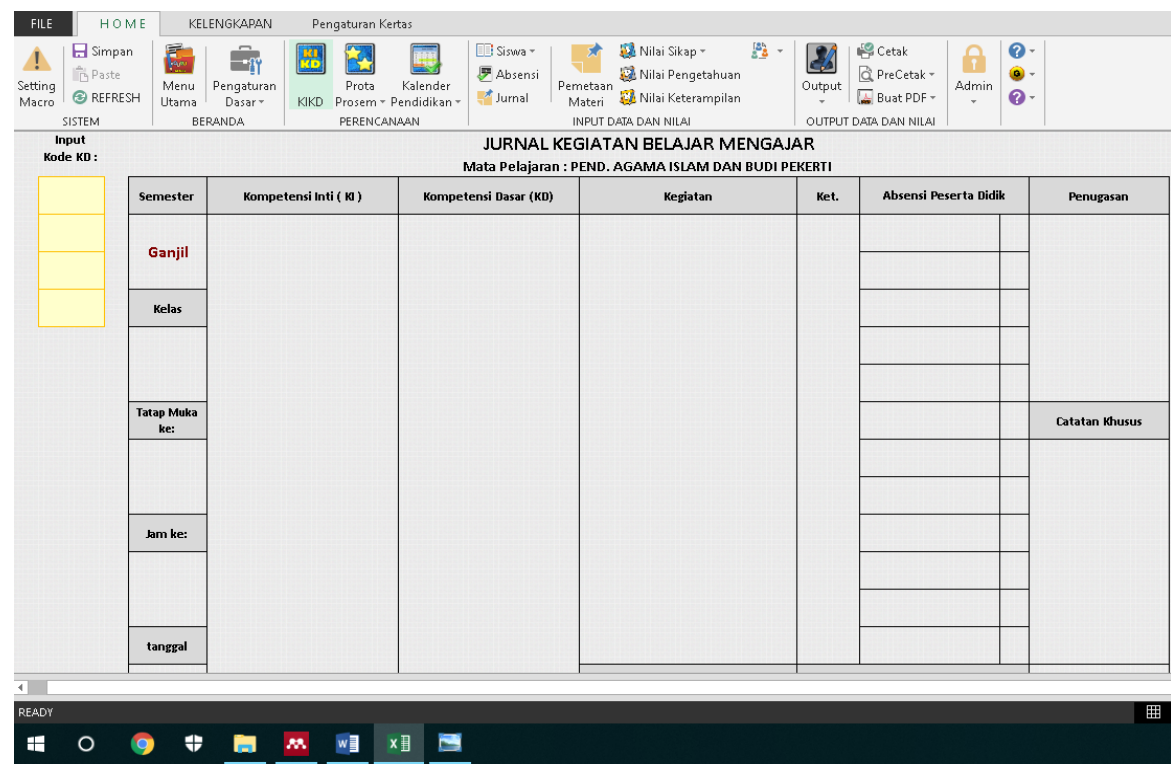

Aspek penilaian yang ketiga yaitu keterampilan pun memiliki pola yang sama. Dengan memanfaatkan instrumen berbasis aplikasi, maka setiap aspek keterampilan peserta didik yang ingin diukur dapat dilakukan oleh pendidik secara cepat sehingga mampu memangkas durasi waktu pengerjaannya. Pendidik tidak lagi harus mencatat tiap detail aspek penilaian keterampilan peserta didik secara manual one by one namun hal tersebut bisa dilakukan dengan pengisian ke dalam kolom-kolom form penilaian keterampilan dalam aplikasi, sebagaimana ilustrasi berikut: 


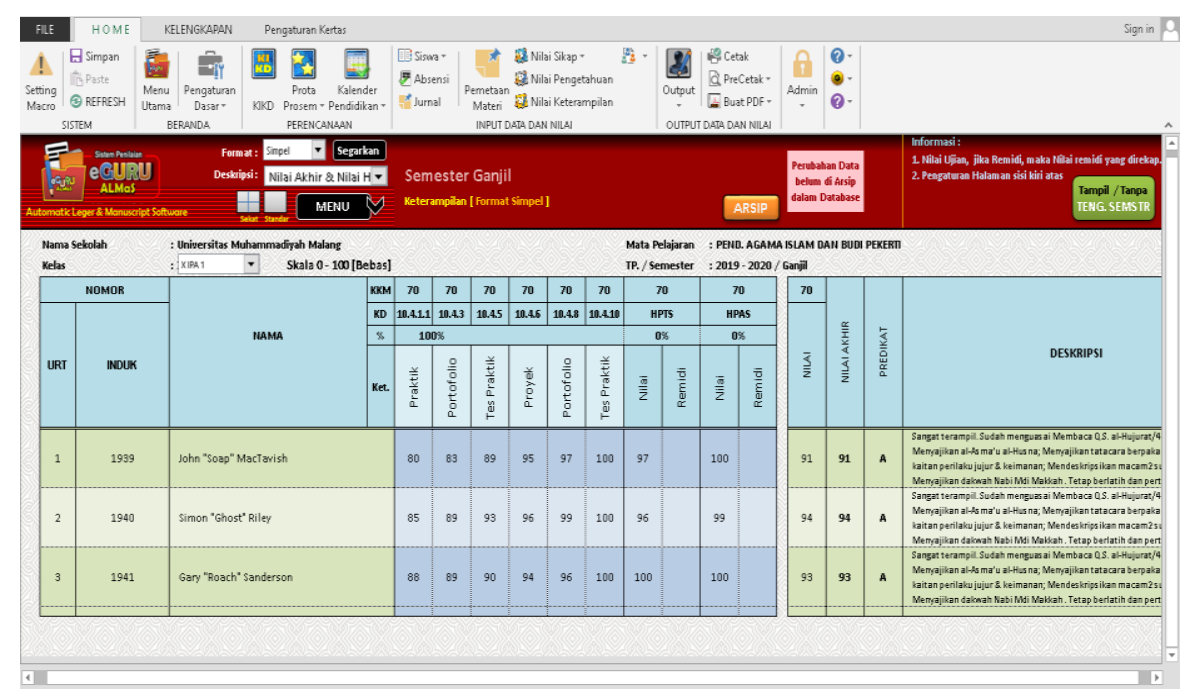

Pengembangan perangkat penilaian pembelajaran PAI sebagaimana narasi di atas, secara analitis dapat ditangkap sebagai salah satu bentuk adaptasi dari konsep penilaian yang dilahirkan oleh Binkley dalam konsep "KSAVE"nya (Abidin, 2016). Kerangka kerja yang diusung dalam konsepnya, Binkley mengklaim lima aspek yang ia sebut dengan akronim KSAVE (Knowledge, Skill, Attitute, Value, and Ethics). Melalui kelima segmentasi tersebut, domain pertama yang menjadi poin penting ialah pada aspek pengetahuan atau pemahaman tertentu sebagai salah satu faktor penting yang harus dikembangkan dalam kompetensi abad 21 dewasa ini. Selanjutnya, domain kedua yang dibidik oleh konsep KSAVE ialah pada aspek sikap (afektif). Pada aspek sikap ini, acuan utama yang dibidik ialah pada sisi perilaku dan bakat peserta didik. Domain ketiga ialah aspek keterampilan yang menitikberatkan pada evaluasi terhadap psikomotor peserta didik.

Penulis memandang kurikulum 2013 revisi yang diterapkan saat ini dapat dianalisa sebagai bentuk adaptasi dari apabila konsep Binkley sebagaimana deskripsi sebelumnya. Melalui pemahaman dan implementasi yang tepat, perangkat penilaian pembelajaran PAI pun pada hakikatnya dapat dicapai melalui media yang sesuai dan linear dengan perkembangan teknologi dan informasi (IT). Basis aplikasi yang digunakan dalam melakukan evaluasi terhadap hasil belajar peserta didik, senyatanya merupakan media yang efektif dalam era kemajuan teknologi informasi dewasa ini. Melalui dialog sinergis antara penilaian PAI dengan penerapan IT, setidaknya akan berimplikasi pada dua hal: pertama, pemanfaatan IT di dalam proses penilaian PAI, akan menambah kompetensi pendidik PAI dalam hal media perangkat pembelajaran. kedua, dengan adanya aplikasi tersebut, akan mampu menunjang dan meningkatkan efisiensi pembelajaran PAI secara didaktis. Maka, pengembangan perangkat pembelajaran melalui implementasi evaluasi berbasis aplikasi menjadi sebuah hal yang krusial dan perlu dipertimbangkan oleh para pendidik yang menginginkan kinerja secara efisien sekaligus komprehensif.

Lazim apabila dikatakan bahwa melalui penerapan perangkat evaluasi pembelajaran berbasis aplikasi tersebut secara teknis-implementatif dapat memberikan efisiensi dan keefektifan bagi pendidik dalam mengolah hasil penilaiannya terhadap para peserta didiknya (Fuady, A., \& Nursit, 2016). Sebagai catatan penting yang perlu diperhatikan ialah kesiapan sarana prasarana satuan pendidikan yang ingin menerapkan pola perangkat evaluasi tersebut. Dengan persinggungan kolaboratif antara konsep penilaian dengan aspek penggunaan IT, maka sisi aksiologis pendidikan Islam dalam implementasi Kurikulum 2013 Revisi khususnya pada aspek evaluasi pembelajarannya- akan dapat dicapai secara integral, komprehensif dan efektif. 


\section{KESIMPULAN}

Penilaian pembelajaran PAI dalam bingkai struktur kurikulum 2013 Revisi, mengharuskan pendidik bersifat proaktif mengembangkan kompetensi yang dimiliki peserta didik dalam tiga aspek, yaitu pengetahuan (kognitif), sikap (afektif) dan keterampilan (psikomotorik). Melalui penilaian autentik dengan format penilaian holistik, diharapkan konsep pendidikan (terutama PAI) menjadi pintu bagi tersemainya potensi peserta didik secara maksimal sehingga menjadi insan produktif yang tetap berpegang pada pengembangan karakter insan kamil: mendidik manusia berkualitas yang akan mampu menjawab dinamisasai tantangan zaman. Guna mencapai sinergitas tujuan pendidikan tersebut, maka evaluasi pembelajaran PAI harus mau dan mampu memanfaatkan teknologi informasi (IT) sebagai media perangkat pembelajaran. Diantara bentuk sinergitas tersebut ialah dengan menggunakan perangkat pembelajaran berbasis aplikasi. Dengan demikian, pengembangan perangkat evaluasi pembelajaran PAI akan mampu merefleksikan hasil belajar peserta didik dengan lebih efektif dan efisien, baik dalam ranah kognitif, afektif, maupun psikomotorik.

\section{REFERENSI}

Abidin, Y. (2016). Revitalisasi Penilaian Pembelajaran dalam Konteks Pendidikan Multiliterasi Abad Ke-21 (1st ed; Nurul Falah Atif, Ed.). Bandung: PT Refika Aditama.

Ach.Sayyi. (2017). Modernisasi Kurikulum Pendidikan Islam dalam Perspektif Azyumardi Azra. Tadris, 12(1), 20-39.

Baswedan, A. (2015). Peraturan Menteri Pendidikan dan Kebudayaan Republik Indonesia Nomor 53 Tahun 2015 Tentang Penilaian Hasil Belajar oleh Pendidik dan Satuan Pendikan pada Pendidkan Dasar dan Menengah. Berita Negara Republik Indonesia Tahun 2015 Nomor 1868. Jakarta.

Dewantoro, M. H. (2014). Posisioning Pendidikan Islam di Era Globalisasi. Al-Misbah, 2(2), 143-159.

Elmer E. Rasmuson Library. (2018). Library Research Process. Retrieved April 4, 2020, from August 1, 2018 website: https://library.uaf.edu/

Friantary, H., \& Martina, F. (2018). Evaluasi Implementasi Penilaian Hasil Belajar Berdasarkan Kurikulum 2013 oleh Guru Bahasa Inggris dan Bahasa Indonesia di MTS Ja-Alhaq Kota Bengkulu. Silampari Bisa: Jurnal Penelitian Pendidikan Bahasa Indonesia, Daerah, Dan Asing, 1(2), 264-283. https://doi.org/10.31540/silamparibisa.v1i2.202

Fuady, A., \& Nursit, I. (2016). Pengembangan Sistem Penilaian Berbasis ICT untuk Meningkatkan Profesionalisme Guru Matematika SMP Kurikulum 2013. Jurnal Pendidikan Matematika, 2(2), $122-131$.

Gahara, B. (2016). IMPLEMENTASI PENILAIAN AUTENTIK PADA PEMBELAJARAN PENDIDIKAN AGAMA ISLAM KURIKULUM 2013. Tanzim: Jurnal Penelitian Manajemen Pendidikan, 1(1), 93-109.

Ghofar, A. (2017). Guru: Digugu Dan Ditiru. Al- Misbah, 5(1), 1-14. Retrieved from http://www.journal2.uad.ac.id/index.php/almisbah/article/download/163/105

Hamidi, N. (2013). Model Pendidikan Karakter Terintegrasi di SMKN 2 Depok Sleman Yogyakarta. AlMisbah, 1(2), 155-172. https://doi.org/10.1192/bjp.111.479.1009-a

Kemendikbud. (2013). Kerangka Dasar dan Struktur Kurikulum 2013. Jakarta.

Mardiana, D., \& Anggraini, D. C. (2019). The effectiveness of utilising web-learning media towards islamic education learning (PAI) outcome in the era of industrial revolution 4.0. International Journal of Innovation, Creativity and Change, 8(1), 80-96.

Nuruzzaman, M. (2015). Faktor-Faktor yang Menghambat Implementasi Kurikulum 2013 di SMKN 1 Seyegan Sleman Jurusan Teknik Gambar Bangunan (TGB). Universitas Negeri Yogyakarta.

Rahmawati, D. (2017). Perbandingan Implementasi Kurikulum 2013 pada Mata Pelajaran PAI dan Budi Pekerti di SD Negeri Gunungsimping 02 Cilacap Tengah dan SD Negeri Kebonmanis 01 Cilacap Utara Kabupaten Cilacap Tahun 2016. Universitas Muhammadiyah Surakarta.

Ramli, M. (2017). MENINGKATKAN AKTIVITAS DAN HASIL BELAJAR PENDIDIKAN AGAMA ISLAM (PAI) SISWA KELAS XI TKR SMK NEGERI 3 BULUKUMBA MELALUI PENERAPAN MODEL PEMBELAJARAN PROBLEM BASED LEARNING (PBL) DENGAN MEMANFAATKAN PERPUSTAKAAN DIGITAL. Jupiter, XVI(1), 67-80.

Riana, I. G. A., Agung, A. A. G., \& Parmiti, D. P. (2016). ANALISIS RENCANA PELAKSANAAN PEMBELAJARAN ( RPP ) UNTUK IMPLEMENTASI KURIKULUM 2013 DI SD NEGERI 3 BANJAR JAWA KECAMATAN BULELENG Jurusan Teknologi Pendidikan. E-Journal Edutech Universitas Pendidikan Ganesha, 5(2), https://ejournal.undiksha.ac.id/index.php/JJTP/art.

Setemen, K. (2010). Pengembangan Evaluasi Pembelajaran Online. Jurnal Pendidikan Dan Pengajaran, 43(3), 
207-214. https://doi.org/10.23887/jppundiksha.v43i3.124

Setiawan, W., Abdulkarim, A., \& Nugraha, E. (2018). Pre-Service Teachers' Digital Literacy: A Leap In Time. JPMIPA: Jurnal Pengajaran MIPA, 23(1). https://doi.org/https://doi.org/10.18269/jpmipa.v23i1.13907

Sutarman. (2013). The Work Hard Ethic of Teacher (Etos Kerja Keras Guru) dalam Pembelajaran sebagai Pilar Pendidikan yang Berkarakter. Al-Misbah, 01(01), 36-60.

Sutarman. (2017). Guru Dan Peserta Didik dalam Perspektif Pendidikan Islam. Al-Misbah, 5(1), 34-50.

Syahid, A. (2018). Komponen Evaluasi Pembelajaran Bidang Studi Pendidikan Agama Islam dan Budi Pekerti. Jurnal Teknologi Pendidikan Madrasah, 1(1), 33-52. https://doi.org/10.5281/zenodo.1148975

Umami, M. (2018). Penilaian Autentik Pembelajaran Pendidikan Agama Islam dan Budi Pekerti dalam Kurikulum 2013. Jurnal Kependidikan, 6(2), 222-232. 